\section{Economic, political, and social determinants of peace}

Sterling Huang and David Throsby

A number of studies have examined the determinants of intranational and international conflict. Economists in particular have looked at the economics of war and the preparation for war, using military or defense expenditure as the primary indicator of a dependent or explanatory variable. ${ }^{1}$ Such expenditure can be seen as defensive if a particular country is not actively engaged in conflict, or offensive if it is engaged in war or preparing for military operations. Either way, economists' use of military or defense expenditure in their analyses of the relationships between these expenditures and a range of economic variables has meant that their studies have been orientated toward the economics of war rather than the economics of peace. While it is certainly true that understanding the economics of war can be regarded as a necessary prerequisite to finding ways toward conflict prevention, the fact remains that to study the economics of peace can provide an alternative and more direct understanding of what makes for a peaceful society. If it is possible to identify what factors are associated with peace within and between countries, it may help in the formulation of policy strategies to improve the prospects for reducing conflict around the world.

In this article we draw on the literature of defense economics to identify economic, political, and social factors that are related to military spending, with a view to formulating testable hypotheses concerning the obverse relationship, i.e., the extent to which such factors might be determinants of peace. On the basis of a review of this literature we put forward three propositions relating to economic, political, and socio-demographic factors respectively that can be hypothesized as determinants of peacefulness. We then proceed to test these propositions by estimating a simple model using OLS regression and principal components analysis for a dataset covering more than 100 countries over the two-year period 2007-2008. In the final section of the article we discuss some implications of our results.

Military expenditure and conflict

\section{Economic variables}

The principal economic variables that have been studied in research work on the determinants and effects of defense expenditure have been the rate of economic growth, the level of inflation, and the importance of external trade to a country's economy. We consider each of these in turn.
First, a large number of studies over a long period of time have examined the relationship between military expenditure and economic growth. Overviews of this area have variously pointed to three different perspectives that have emerged. ${ }^{2}$ The first strand sees defense expenditure as a stimulus to growth, through its effects in increasing aggregate demand, absorbing idle resources, contributing to employment creation, and producing positive externalities especially through technological spillovers. The second strand takes the opposite view, namely that increased military expenditure will retard growth because of the opportunity costs of the resources involved. The third line of argument acknowledges that both of these causal connections may be possible, depending on the particular resource base, stage of development, and structural features of the economy of the country under study. ${ }^{3}$ The conclusion to be drawn is that there appears to be no systematic and generalizable effect in one direction or the other, the actual experience being dependent on a country's particular circumstances.

Second, research into the relationship between military expenditure and inflation has also thrown up a variety of results. ${ }^{4}$ Perhaps unsurprisingly, it appears that defense expenditure could potentially affect the rate of inflation in an economy where there is full employment and full capacity utilization by placing excessive pressure on demand, whereas in an underemployed economy military expenditure is likely to have little or no impact on the price level.

Finally, in regard to external trade we can point to three different hypotheses that have been investigated. The first is that trade reduces conflict because trade is motivated by national needs and hence is likely to generate mutual gains for all parties. A second body of argument states that trade causes conflict by generating friction and intensifying competition among countries. And third, some studies claim that the effect of trade on conflict is mixed or negligible. ${ }^{5}$ Despite the variability of the results from empirical research on the relationship between trade and conflict, it seems plausible to conclude that increased economic interdependence is likely to mean that the parties will have more to lose than gain from conflict, and that therefore trade will tend to diminish conflict rather than increase it.

Political and socio-demographic variables

Political conditions and socio-demographic characteristics provide the context within which the mentioned economic variables operate and need to be taken into accoun in modeling economic relationships. For example, it is plausible to postulate a link between political instability and internal conflict or external aggression. Such a link 
may operate through the effects of political unrest on economic conditions, for example by its influence on holding back economic development. ${ }^{6}$ But political and socio-demographic factors may also play an important role in their own right in determining the peacefulness of countries.

In regard to political factors, several studies provide specific examples and empirical evidence for the relationship between political factors and the level of peacefulness of a country. One study, for example, demonstrates the vulnerability of the capital market to political conditions in a given country, drawing attention to the joint impact of political and economic conditions on the country's peacefulness. Another shows that economic interdependence and democracy have important benefits for peace.

Turning to demographic features, we note that adverse socio-demographic circumstances in a country such as poor health status, low educational levels, or high levels of interethnic intolerance are likely to be associated with increased tendency to violence and conflict. Paul Collier presents a theoretical argument showing that conflict is more concentrated, or the risk of having a conflict is much higher, in countries with less democracy, little education, fast population growth, and ethnic dominance. Geographic dispersion of the population is also important in determining the risk of conflict. ${ }^{8}$

\section{Hypotheses}

Based on the larger literature illustrated by this brief review, this article puts forward hypotheses on the determinants not of the likelihood of war but of the actuality of peace. The hypotheses are grouped under the same three headings-namely economic, political, and socio-demographic factors - and are summarized as follows.

Proposition 1 (economic): Greater peacefulness will be associated with (1) increased prosperity (higher GDP per head, higher growth rates); (2) lower rates of unemployment; (3) a more equal distribution of income; and (4) greater economic engagement with other countries.

Proposition 2 (political): Greater peacefulness will be associated with (1) stronger and more stable political institutions; (2) less corruption; and (3) greater acceptance of civil liberties, free speech, and respect for human rights.

Proposition 3 (socio-demographic): Greater peacefulness will be associated with (1) higher average levels of education; (2) higher average health status; (3) lower population densities and rates of population growth; and (4) less ethnic intolerance.

In the following section, we test these propositions using as the measure of peacefulness of countries around the world the Global Peace Index (GPI) as compiled for the years 2007 and 2008 by the Economist Intelligence Unit on behalf of the Institute for Economics and Peace. ${ }^{9}$ The explanatory variables are derived from data for more than 100 countries over the two year period 2007-2008. Data sources include the Global Market Information Database, the Economist Intelligence Unit, the World
Bank, Transparency International, the United Nations Development Programme, and UNESCO. A model specifying the GPI score as a function of appropriate explanatory variables is estimated using principal components analysis and OLS regression.

\section{Model and data}

The stated hypotheses can be tested simultaneously by formulating a model in which peacefulness is expressed as a function of a series of variables measuring the influences represented in the separate hypotheses. Thus the independent effect of each of the influences is tested under conditions controlling for the effects of all other variables.

The dependent variable in our model is derived from the level of peacefulness of a given country as measured by its GPI score. The original GPI scores as published by the Institute for Economics and Peace range from 1.10 to 3.29, where a higher value indicates less peacefulness. For our purposes we prefer our dependent variable to represent the positive attributes of peacefulness; hence the original GPI scores are subtracted from 4 so that the higher the value of the converted score, the more peaceful is the country.

The explanatory variables and their sources are categorized according to the three groups of factors hypothesized as affecting (positively or negatively) a country's peacefulness. The economic factors are: the rate of economic growth; per capita GDP; income distribution; inflation rate; unemployment rate; and openness of the economy The political factors are: effective democratic governance; level of public-sector corruption; press freedom; and civil liberties. The socio-demographic factors are: education levels of the population; literacy levels of the population; health status of the population; importance of religion in political or social life; and population growth rate.

The variables representing these factors, as well as their measurement and source, are explained in Table A1 (in the appendix). All variables are measured for the years 2007 and 2008 unless otherwise indicated. Table 1 shows summary statistics for all the variables included in the model. The countries contained in the dataset range from some of the least developed to some of the most advanced countries in the world, as is evident from the minima and maxima of the variables such as income, literacy, health, and education. Table 1 illustrates especially the wide variability in some of the economic characteristics, including income distribution, growth, inflation, and unemployment.

Similarly, there are substantial differences in peacefulness among countries as measured by the index used to derive the dependent variable in our model; in the years under review, the Nordic countries including Iceland, Denmark, and Norway were among the most peaceful, while the least peaceful were Iraq, Somalia, Sudan, and Afghanistan. 
(c) www.epsjournal.org.uk - Vol. 6, No. 2 (2011)

Table 1: Summary statistics

\begin{tabular}{llllll} 
Variable & Mean & Median & St.dev. & Min. & Max. \\
PEACE & 0.66 & 0.70 & 0.24 & -0.35 & 1.04 \\
& & & & & \\
GROWTH & 0.05 & 0.06 & 0.04 & -0.02 & 0.23 \\
INCOME & 8.66 & 8.62 & 1.55 & 5.21 & 11.69 \\
DISTR & 39.86 & 37.90 & 10.78 & 3.90 & 74.30 \\
INFL & 8.21 & 6.70 & 6.26 & -5.50 & 35.00 \\
UNEMP & 9.17 & 8.00 & 6.78 & 0.60 & 47.00 \\
TRADE & -0.24 & -0.16 & 0.68 & -5.54 & 1.56 \\
& & & & & \\
GOVERN & 5.48 & 5.71 & 2.35 & 0.00 & 10.00 \\
CORRUP & 5.71 & 6.60 & 2.21 & 0.40 & 8.60 \\
RESTPF & 28.03 & 21.50 & 24.19 & 0.50 & 103.75 \\
LIBRTY & 6.68 & 7.94 & 2.75 & 0.59 & 10.00 \\
& & & & & \\
EDUC & 12.09 & 12.26 & 3.63 & 2.80 & 20.69 \\
LITRCY & 83.74 & 90.90 & 18.45 & 20.00 & 99.90 \\
HEALTH & 67.57 & 71.36 & 12.04 & 34.97 & 82.08 \\
RELIG & 2.83 & 3.00 & 1.16 & 1.00 & 5.00 \\
POP & 0.63 & 0.68 & 0.74 & -0.93 & 3.11 \\
\hline
\end{tabular}

\section{Results}

We estimate the model outlined above in two ways. First, we use ordinary least squares (OLS) to regress the log of the peacefulness score on the independent variables as a means of identifying the effects of individual variables when the other explanatory variables are held constant. We then employ a second estimation procedure, principal components analysis (PCA), to check the validity of our findings. This approach allows us to examine the influence of groups of variables on the level of peacefulness and provides an independent assessment of the robustness of the model.

\section{Model estimation via OLS regression}

Results of the OLS estimation of the model are shown in Table 2. Looking first at Proposition 1 that relates to the economic factors, we note that the most significant influence on peacefulness appears to be the openness of the economy, with a strong
Table 2: OLS model estimation (dependent variable: PEACE)

$\begin{array}{llll}\text { Variable } & \begin{array}{l}\text { Regression } \\ \text { coefficient }\end{array} & \begin{array}{l}\text { t-ratio } \\ (d f=236)\end{array} & p \text {-value } \\ \text { GROWTH } & 0.4133 & 1.30 & 0.194 \\ \text { INCOME } & -0.0293^{*} & -1.76 & 0.080 \\ \text { DISTR } & -0.0020 & -1.49 & 0.137 \\ \text { INFL } & -0.1972 & -1.07 & 0.286 \\ \text { UNEMP } & -0.2251 & -0.89 & 0.375 \\ \text { TRADE } & 0.0414^{* * *} & 3.00 & 0.003 \\ & & & \\ \text { GOVERN } & 0.0259^{* *} & 2.18 & 0.031 \\ \text { CORRUP } & -0.0289^{* * *} & -3.18 & 0.002 \\ \text { RESTPF } & -0.0024^{* * *} & -2.68 & 0.008 \\ \text { LIBRTY } & -0.0243^{* *} & -2.12 & 0.035 \\ & & & \\ \text { EDUC } & 0.0056 & 0.92 & 0.358 \\ \text { LITRCY } & 0.0016 & 1.33 & 0.185 \\ \text { HEALTH } & 0.0012 & 0.66 & 0.510 \\ \text { RELIG } & -0.0371^{* * *} & 2.77 & 0.006 \\ \text { POP } & -1.8563 & -0.79 & 0.432 \\ & & & \\ \text { TIME } & 0.0237 & 1.07 & 0.285 \\ \text { CONSTANT } & 1.0947^{* * *} & 6.05 & 0.000\end{array}$

$\mathrm{n}=253 ; \mathrm{R}^{2}=0.5232 ;$ adj. $\mathrm{R}^{2}=0.4909 ; \mathrm{F}=26.08 * * * ;$ variance of the estimate $=0.0283$; sum of squared errors $=6.6828$; mean of dependent variable $=0.6604 ; * * *, * *$, and $*$ indicate significance at $1 \%, 5 \%$, and $10 \%$ levels, respectively.

positive effect apparent in the trade variable. The coefficient on this variable indicates that a 1 percent increase in the annual value of a country's trade would result in a change in the raw score for the peacefulness variable of approximately exp(0.04), equivalent to an increase of about 30 places in the country's peacefulness ranking amongst 128 countries.

Among the other economic factors, it appears that the growth rate rather than the level of income is a determinant of peacefulness, although the positive coefficient on the growth variable is not significant. Greater equality in the distribution of income is associated with greater peacefulness, although the coefficient on this variable is not 
statistically significant. The remaining economic variables have signs consistent with Proposition 1, but are not statistically significant.

Greater peacefulness is strongly related to the first three political factors as listed in Proposition 2: Countries with more strongly developed and well-functioning democratic governance clearly tend to be more peaceful, as do countries with lower levels of public sector political corruption, and countries with more press freedom. Our results suggest that a 1-unit increase in a country's governance score, or a 1-unit decrease in its corruption index, would improve the country's peacefulness ranking by up to 30 positions. However, our results do not support the remaining element in Proposition 2: instead, they indicate a negative rather than the expected positive effect of the observance of civil liberties.

The most influential factor to emerge among the socio-demographic factors included to test Proposition 3 is the religious variable. It must be noted that this provides only indirect evidence relating to the fourth element in this Proposition, namely ethnic intolerance. All that we can say is that our results indicate a greater level of peacefulness to be evident in more secular societies. Other socio-demographic factors are not statistically significant in affecting peacefulness, although at least we can say that the coefficients on education, literacy levels, and health status have the expected positive sign.

Alternative estimation via PCA

A potential problem with the OLS estimation is that coefficient estimates and the resulting statistical inference are sensitive to the degree of correlation among the explanatory variables. The possible presence of multicollinearity in our empirical model can be assessed by examination of the simple correlation matrix for the independent variables. Shown in Table A2, the data indicate that, although we do not have anything approaching perfect multicollinearity, some of the variables show moderate correlation, for example between income, health status, and education. It is therefore important to apply an alternative analytical method to check our results. Such an alternative approach is provided by PCA.

The logic of applying PCA to our model is that this technique allows us to derive a reduced set of factors - in effect, a set of orthogonal (uncorrelated) latent variables - that reproduce the total system variability and can be used to explain the underlying structure of the data in a more meaningful way. Moreover, once these principal components have been identified, they can be used as explanatory variables in a regression with the original dependent variable on the left-hand-side. Given that the factors are orthogonal to each other, we avoid the problem arising from multicollinearity.

Estimation of the principal components yields a series of variables, the first of which has maximal overall variance, the second has maximal variance among all unit-length linear combinations that are uncorrelated to the first principal component, and so on. The last principal component has the smallest variance among all unit-length linear combinations of the variables. All principal components combined contain the same information as the original variables, but the important information is partitioned over the components in a particular way: In particular, the components are uncorrelated with each other, and earlier components contain more information than later components. PCA thus conceived is simply a linear transformation of the data that is equivalent to factor analysis when we assume that all the variations in the covariance matrix are fully captured by the independent variables. In our present analysis, given that our choice of independent variables includes most of the factors that are known a priori to influence either peace or military expenditure, such an assumption appears to be reasonable.

To carry out the PCA, we first perform spectral decomposition on the covariance matrix, with the resulting collection of eigenvectors forming the so-called factor loading matrix; each column in the factor loading matrix represents the weights placed on the original variables, and the principal component is constructed as the product of weight and original variable. The pattern of weights suggests what each latent variable is measuring, with the absolute value of the weights indicating the relative importance of each explanatory variable in the model in forming that principal component. The loading matrix for the first six components from this analysis is shown in Table 3.

The results in Table 3 show that the first six principal components (PC1 to PC6) explain just over 80 percent of the variance. Note that the contribution of each principal component in explaining the total variance is in descending order, i.e., PC2 contributes less than PC1, PC3 less than PC2, and so on. We can see from Table 3 that in our analysis PC1, and to a lesser extent PC2, load heavily on the political and socio-demographic factors in our model. The remaining principal components reflect how different economic factors influence peacefulness. PC3 captures the effect of openness of the economy, with a weight of 0.742 attached to the trade variable; the significance of a country's growth rate rather than its level of per capita GDP is also highlighted in this component. Unemployment is prominent in PC4, while inflation, income distribution, and again the growth rate appear in PC5 and PC6.

To complete the analysis we regress the original dependent variable, PEACE, on these six principal components. The results, as shown in Table 4, are consistent with the original model estimation in Table 2. Using only six principal components, rather than 15 independent variables, the regression in Table 4 explains a similar proportion of the variance, and the overall PCA reflects the same pattern of influence of the explanatory variables as in the earlier OLS analysis.

We can conclude that despite the moderate collinearity in the original OLS estimation, we are justified in using the model put forward in this article as a basis for testing our hypotheses concerning the influence of economic, political, and socio-demographic variables on peacefulness. 
Table 3: Loading matrix for the first six principal components

$\begin{array}{lrrrrrr}\text { Variable } & \text { PC1 } & \text { PC2 } & \text { PC3 } & \text { PC4 } & \text { PC5 } & \text { PC6 } \\ & & & & & & \\ \text { GROWTH } & 0.180 & 0.220 & 0.454 & 0.077 & 0.435 & 0.027 \\ \text { INCOME } & -0.327 & 0.157 & 0.168 & -0.076 & -0.138 & -0.188 \\ \text { DISTR } & 0.169 & -0.416 & 0.041 & -0.169 & 0.373 & -0.682 \\ \text { INFL } & 0.202 & 0.223 & -0.366 & -0.037 & 0.414 & 0.291 \\ \text { UNEMP } & 0.081 & -0.152 & 0.066 & -0.833 & -0.152 & 0.192 \\ \text { TRADE } & -0.103 & -0.064 & 0.742 & 0.031 & 0.115 & 0.257 \\ & & & & & & \\ \text { GOVERN } & -0.315 & -0.279 & -0.135 & 0.156 & 0.048 & 0.001 \\ \text { CORRUP } & 0.329 & 0.065 & -0.033 & -0.192 & -0.207 & 0.026 \\ \text { RESTPF } & 0.241 & 0.463 & -0.075 & 0.012 & -0.053 & -0.287 \\ \text { LIBRTY } & -0.299 & -0.352 & -0.124 & -0.082 & 0.231 & 0.094 \\ & & & & & & \\ \text { EDUC } & -0.334 & 0.152 & -0.016 & -0.093 & 0.025 & -0.197 \\ \text { LITRCY } & -0.294 & 0.271 & 0.024 & -0.203 & 0.337 & -0.257 \\ \text { HEALTH } & -0.302 & 0.332 & 0.014 & -0.071 & -0.140 & -0.176 \\ \text { RELIG } & 0.228 & 0.038 & 0.134 & -0.205 & -0.407 & -0.177 \\ \text { POP } & 0.278 & -0.219 & 0.129 & 0.315 & -0.211 & -0.229\end{array}$

Cumulative proportion of variance explained (\%)
43.8
54.2
$62.3 \quad 70.0$
$75.6 \quad 80.5$

Table 4: Principal components regression (dependent variable: PEACE)
Variable

\section{Regression} coefficients

\section{t-ratio}

$(d f=236)$

PC1

PC2

PC3

$\begin{array}{lr}-0.0223^{* * *} & -9.01 \\ 0.00971 * * * & 4.33 \\ 0.0533^{* * *} & 3.59 \\ 0.1243^{* * *} & 7.14 \\ 0.0369 * * * & 5.55 \\ -0.01451 * * * & -4.01 \\ 0.8899 * * * & 7.90\end{array}$

0.00

0.00

0.00

0.00

0.00

PC5

CONSTANT
7.90 $\mathrm{n}=253 ; \mathrm{R}^{2}=0.5027 ;$ adj. $\mathrm{R}^{2}=0.4905 ; \mathrm{F}=41.63^{* * *}$; variance of the estimate $=0.0283$; sum of squared errors $=6.9706$; mean of dependent variable $=$ $0.6604 ; * * *$ indicates significant at $1 \%$ level.

\section{Conclusions}

We began this article by pointing out that we know quite a lot about the economics of war, but rather less about the economics of peace. In the article we have drawn insights from the literature in defense economics to suggest some important variables that could be hypothesized to be determinants of the absence rather than the presence of conflict; in other words we have addressed the question: What are the major factors likely to lead countries toward peacefulness? We categorized these factors in three groups-economic, political, and socio-demographic — and put forward hypotheses to identify causal connections involved. We then proceeded to test the hypotheses using data for 2007 and 2008, covering more than 100 countries, with peacefulness measured by the Global Peace Index.

Our results show that all three groups of factors play some part in contributing toward peacefulness in a country. We find that among the economic factors, the most important influence is exerted by the openness of the economy. This is a significant result in the context of ongoing efforts within the WTO to reduce barriers to international trade, especially through providing improved access for exports from poor countries into markets in the developed world. It suggests that as well as promoting economic development, freer trade is likely to have benefits for affected countries through encouraging peacefulness, other things being equal. Our finding in regard to the openness of the economy also supports other research that points to intercultural dialogue, closer diplomatic ties, and social and cultural interrelationships between countries as means toward reducing the potential for conflict.

Also among the economic factors, our results indicate that economies with high growth rates are likely to be more peaceful than those experiencing slower growth. However, as Amartya Sen has pointed out, rapid growth on its own does not guarantee social progress. Much depends on how the benefits of growth are distributed: It is important that they are not captured by sectional interests but distributed equitably, especially in pursuit of poverty alleviation objectives. ${ }^{10}$ Our results suggest that there is an additional payoff to equitable growth, one measured in terms of peacefulness.

Political factors emerge as particularly significant in our analysis. The results lend weight to the proposition that a properly constituted, well-functioning democratic system of governance free of political corruption is an important requirement for the achievement of a peaceful society. Many examples exist in the contemporary world where countries subject to nondemocratic government are prone to internal and external conflict. Our results suggest that popular support in such countries for a more democratic political system might, if successful, lead not only to improvements in civil rights but also to greater peacefulness.

Not only is a well-governed society likely to avoid internal conflict, it may also be more capable of responding to popular demand for a greater sense of peace and security in the everyday lives of its people. Peacefulness is, in economic terms, a public good, and a polity well-attuned to the demands for collective goods in general 
might be expected to heed the people's will in its peace-related activities. As a public good, the demand for peacefulness could be measured using the methods of nonmarket valuation that have been used to assess the demand for security expressed through preferences for different levels of military expenditure. ${ }^{11}$

Finally, of the three groups of factors influencing peacefulness, we find the least strong effects among the socio-demographic characteristics of a country's population. There is some limited evidence in our results for a greater level of peacefulness to be associated with positive human development indicators such as literacy, education, and health. Countries with low rates of population growth, mostly in the developed world, also tend to be more peaceful. The one statistically significant factor among the socio-demographic variables is that measuring the importance of religion in politics and in social life. We find that secular societies tend to be more peaceful than those characterized by a politically influential state religion.

The model presented in this article represents only a partial explanation of factors associated with peace. Data limitations and specification problems mean that potentially significant variables had to be omitted, such as the influence of international networks and alliances. Furthermore, different insights may be possible if the model could be estimated for given countries or groups of countries using time-series rather than cross-section data. Clearly more research in this important area is needed.

Notes

Sterling Huang, a former staff member of the Department of Accounting at Macquarie University, Sydney, Australia, is currently a PhD student at INSEAD, Singapore. He may be reached at <sterling.huang@insead.edu>. David Throsby, the corresponding author, is Professor of Economics at Macquarie University, Sydney, Australia. He may be reached at < david.throsby@mq.edu.au>. With the usual caveat, the authors acknowledge the helpful comments of two referees on earlier versions of this article.

1. See, for example, contributions to Sandler and Hartley (2007).

2. Such as those of Dreze (2006); Brauer (2007); Dunne (2009); Hartley (2010).

3. First: e.g., Atesoglou (2002); Aslam (2007); Kollias, et al.( 2007). Second: Mylonidis (2008); Pieroni (2009). Third: e.g., Aizenman and Glick (2006); Kollias and Paleologou (2010).

4. Sandler and Hartley (1998); Tzeng, et al. (2008).
5. First: Gartzke, et al.(2001); Polachek, et al. (2005); Dorussen (2006); Polachek (2007). Second: Barbieri (2002). Third: Martin, et al. (2008).

6. See for example assessments of the effects of political instability on economic development in Sub-Saharan Africa (Fosu, 2004) and in the Middle East and North African region (Tosun, et al. 2008).

7. See an overview in Goldstone, et al. (2010). One study: Gartzke, et al. (2001) Another: Oneal and Russett (1999).

\section{Collier (2006).}

9. Institute for Economics and Peace (2008).

10. See, for example, Sen (2011).

11. See, for example, Throsby and Withers (2001).

\section{References}

Aslam, R. 2007. "Measuring the Peace Dividend: Evidence from Developing Economies.” Defence and Peace Economics. Vol 18 No. 1 pp. 39-52.

Atesoglou, H.S. 2002. "Defense Spending Promotes Aggregate Output in the United States: Evidence from Co-integration Analysis.” Defence and Peace Economics. Vol. 13, No. 1, pp. 55-60.

Aizenman, J. and R. Glick 2006. "Military Expenditure, Threats, and Growth." Journal of International Trade and Economic Development. Vol. 15, No. 2, pp. 129-155.

Barbieri, K. 2002. The Liberal Illusion: Does Trade Promote Peace? Ann Arbor, MI: University of Michigan Press.

Brauer, J. 2007. "Review Article: Is War Necessary for Economic Growth?" Economics of Peace and Security Journal. Vol. 2, No. 1, pp. 71-76.

Collier, P. 2006. "Economic Causes of Civil Conflict and Their Implications for Policy.” Working Paper, Department of Economics, Oxford University.

Dorussen, H. 2006. "Heterogenous Trade Interests and Conflict: What You Trade Matters.” Journal of Conflict Resolution. Vol. 50, No. 1, pp. 87-107.

Dreze, J. 2006. “Military Expenditure and Economic Growth,” pp. 377-382 in D.A Clark, ed. The Elgar Companion to Development Studies, Cheltenham: Edward Elgar.

Dunne, J.P. 2009. "Defence Spending and Development/Modernisation,” ch. 23 in A.T.W. Tan, ed. The Global Arms Trade: A Handbook, London: Routledge.

Fosu, A.K. 2004. "Mapping Growth into Economic Development: Has Elite Political 
Instability Mattered in Sub-Saharan Africa?” American Journal of Economics and Sociology. Vol. 63, No. 5, pp. 1173-1192.

Gartzke, E., Q. Li, and C. Boehmer 2001. "Investing in the Peace: Economic Interdependence and International Conflict.” International Organisation. Vol 55, No. 2, pp. 391-438.

Hartley, K. 2010. “Defense Economics,” pp. 79-95 in W.B. Rouse, ed. The Economics of Human Systems Integration: Valuation of Investment in People's Training and Education, Safety and Health, and Work Productivity. Hoboken, NJ: Wiley.

Institute for Economics and Peace 2008. Global Peace Index: 2008 Methodology, Results and Findings. St. Leonards: IEP.

Kollias, C., N. Mylonidid, and S-M. Paleologou 2007. “A Panel Data Analysis of the Nexus Between Defence Spending and Growth in the European Union.” Defence and Peace Economics. Vol. 18, No. 1, pp.75-85.

Kollias, C. and S-M. Paleologou 2010. “Growth, Investment and Military Expenditure in the European Union.” Journal of Economic Studies. Vol. 37, No. 2, pp. 228-240.

Martin, P., T. Mayer, and M. Thoenig. 2008. "Make Trade Not War?” Review of Economic Studies. Vol. 75, No. 3, pp. 865-900.

Mylonidis, N. 2008. "Revisiting the Nexus between Military Spending and Growth in the European Union.” Defence and Peace Economics. Vol. 19, No. 4, pp. 265-272.

Oneal, J and B. Russett 1999. “Assessing the Liberal Peace with Alternative Specifications: Trade Still Reduces Conflict.” Journal of Peace Research. Vol 36, No. 4, pp. 423-442.

Pieroni, L. 2009. "Military Expenditure and Economic Growth.” Defence and Peace Economics. Vol. 20, No. 4, pp. 327-339.

Polachek, S. 2007. "How Trade Affects International Interactions.” Economics of Peace and Security Journal. Vol. 2, No. 2, pp. 60-68.

Polachek,S., C. Seiglie, and J. Xiang 2005. "Globalization and International Conflict: Can FDI Increase Peace?” Working Paper \#2005-004. Newark, NJ: Rutgers University.

Sandler, T and K. Hartley 1998. The Economics of Defence. Cambridge: Cambridge University Press.

Sandler, T and K. Hartley, eds. 2007. Handbook of Defense Economics. Vol. 2. Amsterdam: Elsevier/North-Holland.

Sen, A. 2011. “Quality of Life: India vs. China.” The New York Review. Vol. LVIII, No. 8, pp. 44-45.

Throsby, D. and G.A. Withers. 2001. "Individual Preferences and Demand for Military Expenditure.” Defence and Peace Economics. Vol. 12, No. 2, pp. 87-102.

Tosun, M.U., M.C. Gran, and A. Ulucan. 2008. "The Political Instability, Investment Profile and the Macroeconomic Performance of the Middle East and North Africa
(MENA) Region.” Problems and Perspectives in Management. Vol. 6, No. 2, pp. 31-38.

Tzeng, S., C. Lai, and C. Huang 2008. "Does Military Expenditure Matter for Inflation and Economic Growth?” Defense and Peace Economics. Vol 19, No. 6 , pp. 471-478. 
Appendix. Table A1: Dependent and explanatory variables

\section{Variable}

PEACE: level of peacefulness

\section{ECONOMIC}

GROWTH: rate of economic growth

INCOME: per capita income

DISTR: income distribution

INFL: rate of price inflation

UNEMP: level of unemployment

TRADE: openness of the economy

\section{POLITICAL}

GOVERN: functioning of government

CORRUP: level of public sector corruption

RESTPF: restrictions on press freedom

LIBRTY: civil liberties

\section{Definition}

Log of converted score on Global Peace Index for 2007 and 2008 (details see text)

Real GDP growth rate (\%) in 2007-08

Log of GDP per capita (USD, 2008)

Gini coefficient (\%) for 2007-08

Annual inflation rate (\%) in 2007-08

Annual unemployment rate (\%) in 2007-08

Log of exports plus imports as a percentage of GDP (\%)

\section{Source}

Institute for Economy and Peace (IEP)

GMID

GMID

UN Human Development Index; EIU

GMID

EIU

EIU

EIU Democracy Index determine government policy and whether there is an effective system of checks and balances on the exercise of government authority. Ranked from 1 to 10 , with 1 indicating low level of functioning/governance

Index drawing on multiple expert opinion surveys that poll perceptions of public sector corruption scoring countries on a scale from $0-10$, with 0 indicating high levels of perceived corruption and 10 indicating low levels of perceived corruption.

Index reflecting the degree of freedom journalists and news organisations enjoy in each country, and the efforts made by the state to respect and ensure respect for this freedom. The score ranges from 0 to 100, with 100 indicating the highest level of restriction on press freedom.

Index representing qualitative assessment of the prevalence of civil liberties based on a questionnaire. Ranked from 1-10, with 1 indicating very low and 10 indicating very high.
Transparency International, Corruption Perception Index

Reporters without Borders 


\section{SOCIO-DEMOGRAPHIC}

EDUC: level of education

LITRCY: adult literacy

HEATLH: health status of population

RELIG: importance of religion in national life

POP: projected population growth rate

TIME: dummy variable
Mean years of schooling primary to tertiary

Adult literacy rate as a percentage of population over the age of 15

Life expectancy at birth is the number of years a newborn infant would live if prevailing patterns of mortality at the time of its birth were to stay the same throughout its life

Index representing qualitative assessment of the level of importance of religion in politics and social life. Ranked from 1 to 5 (very low to very high)

Projected annual population growth from 2004 to 2050 (\%, not compounded)

$2007=0 ; 2008=1$

\section{UNESCO}

UNDP, Human Development Report

World Bank, World Development Indicators

EIU

UN Population Reference Bureau

\section{Abbreviations:}

GMID: Global Market Information Database

EIU: Economist Intelligence Unit

UNDP: United Nations Development Programme

UNESCO: United Nations Educational, Scientific and Cultural Organization 
The Economics of Peace and Security Journal, ISSN 1749-852X

(C) www.epsjournal.org.uk - Vol. 6, No. 2 (2011)

Table A2: Simple correlation matrix for independent variables
(1) (2)
(3)

(4)

(5)

(6)

$-0.29$

(1) GROWTH

(2) INCOME

(3) DISTR

$\begin{array}{ll}0.13 & -0.38\end{array}$

(4) INFL

$\begin{array}{lll}0.21 & -0.45 & 0.11\end{array}$

(5) UNEMP

$\begin{array}{llll}0.01 & -0.11 & 0.19 & 0.04\end{array}$

(6) TRADE

$\begin{array}{lllll}0.10 & 0.27 & -0.07 & -0.28\end{array}$

(7) GOVERN

(8) CORRUP

$\begin{array}{llll}-0.43 & 0.54 & -0.21 & -0.40\end{array}$

$\begin{array}{lllll}0.40 & -0.78 & 0.39 & 0.48\end{array}$

$\begin{array}{llll}0.32 & -0.42 & 0.11 & 0.39\end{array}$

(10) LIBRTY

$\begin{array}{llll}-0.40 & 0.46 & -0.10 & -0.35\end{array}$

(11) EDUC

$\begin{array}{llll}-0.35 & 0.74 & -0.37 & -0.39\end{array}$

(12) LITRCY

(13) HEALTH

(14) RELIG

$\begin{array}{llll}-0.17 & 0.70 & -0.25 & -0.22\end{array}$

$\begin{array}{llll}-0.29 & 0.73 & -0.48 & -0.32\end{array}$

$\begin{array}{llll}0.24 & -0.39 & 0.21 & 0.23\end{array}$

$\begin{array}{llll}0.29 & -0.55 & 0.41 & 0.21\end{array}$

(15) POP

$\begin{array}{rr}-0.24 & 0.12 \\ 0.23 & -0.21\end{array}$

$0.02-0.25$

$-0.06 \quad 0.15$

$-0.74$

$-0.63 \quad 0.52$

$\begin{array}{lllll}-0.14 & 0.18 & 0.60 & -0.66 & -0.36\end{array}$

$\begin{array}{lllll}-0.14 & 0.17 & 0.45 & -0.49 & -0.30\end{array}$

$\begin{array}{lllll}-0.20 & 0.16 & 0.48 & -0.59 & -0.23\end{array}$

$\begin{array}{lllll}0.21 & -0.11 & -0.46 & 0.50 & 0.30\end{array}$

$\begin{array}{lllll}-0.01 & -0.11 & -0.45 & 0.42 & 0.30\end{array}$

0.59

$0.48 \quad 0.73$

$\begin{array}{ll}0.44 & 0.73\end{array}$

$-0.44$

$-0.46$

0.70

$-0.41-0.27$

$-0.69-0.60$ 